\title{
Granger Causality Analysis of Foreign Trade Impact on Economic Growth: Case of Azerbaijan
}

\author{
YEGANA ALIKHANLI \\ Finance Department \\ Baku State University \\ Azercell Plaza, Tbilisi avenue 149, Baku \\ AZERBAIJAN
}

\begin{abstract}
Main purpose of the investigation is to define existing of causality relationship between foreign trade activity of Azerbaijan and economic growth. There were used OLS method and cointegration between some macroeconomic indicators. Main conclusion is that there is not causality effect between import and GDP, but GDP growth is cause for changing import for lag=3. As well as there is causality effect between GDP growth and export. But there is not strong causality effect between foreign trade openness, foreign trade freedom and economic growth.
\end{abstract}

Key-Words: foreign trade; import; export; Granger causality; trade freedom; foreign trade openness; trade balance; GDP

Received: October 3, 2019. Revised: May 19, 2020. Accepted: May 25, 2020. Published: May 29, 2020.

\section{Introduction}

One of the important factors for economic development in any country is foreign trade. Both aspects of foreign trade, i.e. imports, and exports, have a certain effect on the country's gross domestic product (GDP). In the calculation of the GDP of each country by the cost method, the volume of imports is included as a negative factor and the volume of exports as a positive factor. However, the impact of foreign trade on GDP or economic growth, its quantitative assessment is not so simple. Compliance with modern econometric requirements in conducting such assessments has a significant impact on the quality of calculations. Thus, econometric calculations must meet scientifically reliable criteria. One of such reliability criteria is to check the indicators with various econometric tests before performing regression analyses.

In our study, we looked at the dependence of gross domestic product on imports, exports, trade balances, and total trade, as well as dependence on foreign trade freedom and openness. It is necessary to assess and improve government policy on foreign trade. For this purpose, we need to determine in advance how reliable the regression dependencies between these indicators are. The most common of such tests in economic theory is to check the stationarity of the indicators, e.g. by the DickeyFuller test, is widely used.

\section{Literature review}

It should be noted that the impact of foreign trade, especially exports, on economic growth in different countries leads to different results. Akanni (2007) econometrically calculates the effects of oil exports on economic growth using the least squares method, concluding that the effects of investment in the oil sector and oil rents on economic growth are positive. However, in some African countries, oil rents do not provide economic growth. An econometric analysis of the impact of Nigeria's oil export revenues on economic growth also suggests that while oil exports have had some effect on economic growth, they are not significant. Akanni analyzes the effects of Indonesian exports on economic growth with the VAR model and concludes that such effects are strong for Indonesia [1]. Gemechu uses the method of cointegration and error correction to show that there is a significant link between exports and economic growth for Abyssinia [2]. Erfani studied the effects of export activity on economic growth for Asian and Latin American countries between 1965 and 1995 and concluded that there was a positive relationship between these two indicators [3]. Studies for India, Pakistan, the Philippines, Malaysia and Thailand from 1973 to 1993 also show a positive link between exports and economic growth, as well as the liberalization of foreign trade and the increase in exports and foreign investment [4].

Balaguer compares the economic development of middle-income countries with less export-oriented countries than those with export-oriented countries and concludes that the former have faster growth [5]. These studies also show that any form of government support for exports does not have a significant impact on economic growth. Lin analyzed the state of the Chinese economy in the 1990s using a new valuation method and proved that 
a ten percent increase in China's exports leads to a one percent increase in the economy [6].

Almost all countries have rules restricting imports. Singapore, the world's most liberal import regime, also has some restrictions on the import of certain goods and services [7]. Some countries, even the United States and European countries, which promote globalization and trade liberalization in the world, try to limit their imports to a certain extent.

\subsection{Methodology}

We will make sure that there is a correct regression relationship between the studied indicators by checking the periodicity of the time sequence of these indicators. If in the initial approach we will consider that $\mathrm{y}_{\mathrm{t}}=\rho * \mathrm{y}_{\mathrm{t}-1}+v_{\mathrm{t}}$ dependent, or $\mathrm{y}_{\mathrm{t}}=\alpha+\rho * \mathrm{y}_{\mathrm{t}-1}+v_{\mathrm{t}}$ dependent $|\rho|<1$ if so, then $y_{t}$ is a stationary time sequence. This first-degree autoregression will be considered AR (1). Here $\mu=\mathrm{E}\left(y_{t}\right) \mathrm{y}_{\mathrm{t}^{-}}$is a mathematical expectation of the time sequence.

In the next approximation, we will use a DickeyFuller test ( $\alpha$ stable but not trending) to increase the accuracy of the regression relationship. That is, we will assume that

$\Delta \mathrm{y}_{\mathrm{t}}=\alpha+\gamma * \mathrm{y}_{\mathrm{t}-1}+v_{\mathrm{t}}$ dependent

$\mathrm{H}_{0}: \rho=1 \sim \mathrm{H}_{0}: \gamma=0$ if so, the $\mathrm{y}_{-} \mathrm{t}$ time sequence is not stationary.

However, if $\mathrm{H}_{1}: \rho<1 \sim \mathrm{H}_{1}: \gamma<0$ and $\tau<$ $\tau_{c}$ then the time sequence $y_{t}$ is stationary.

Here $\tau_{c}$-are critical values for tau statistics. The estimates proposed by R. Davidson and J.G. MacKinnon (1993) will be taken as the critical values of the tau statistics during the calculations.

It is not correct to determine the extent to which foreign trade activity affects economic growth in terms of multiple regression alone. Because a simple linear regression relationship between two indicators does not indicate a cause-and-effect relationship between these indicators. In other words, the connection can be "fake". Therefore, the Granger causality test is used to determine whether the relationship with specific econometric tests is false and whether the relationship between the indicators is a "cause-and-effect" relationship. The Granger causality test allows the prediction of another time series through one-time series. It should be noted that such a prediction is necessary, but not sufficient, for the necessity of a cause-andeffect relationship.

\section{Results}

\subsection{Causality relationship between import and GDP}

The Granger test can be performed for $\dot{I} M P_{t}$ and $G D P_{t}$. However, it should be noted that none of these time series is stationary to degree I (0). However, the simple linear regression dependence between these two indicators is quite strong $\left(R^{2}=\right.$ 0.86). The F-significance level is $2 * 10^{-10}$. However, this does not mean that there is a causeand-effect relationship. Granger test shows no causal relationship between these two indicators (Table 2).

Table 2

The results of the Granger test on the effects of imports on GDP and vice versa in Azerbaijan.

\begin{tabular}{|l|c|c|c|}
\hline & \multicolumn{3}{|c|}{ Lag=1 } \\
\cline { 2 - 4 } & $\begin{array}{c}\mathrm{F}- \\
\text { statistics }\end{array}$ & $\begin{array}{c}\text { P- } \\
\text { probability }\end{array}$ & hypothesis \\
\hline $\begin{array}{l}\mathrm{I} M P_{t} \\
\rightarrow G D P_{t}\end{array}$ & 0.33 & 0.57 & $H_{0}$ \\
\hline $\begin{array}{l}G D P_{t} \\
\rightarrow \mathrm{I} M P_{t}\end{array}$ & 1.67 & 0.21 & $H_{0}$ \\
\hline
\end{tabular}

\begin{tabular}{|c|c|c|c|c|c|}
\hline \multicolumn{3}{|c|}{ Lag=2 } & \multicolumn{3}{c|}{ Lag=3 } \\
\hline $\begin{array}{c}\text { F- } \\
\text { statis } \\
\text { tics }\end{array}$ & $\begin{array}{c}\text { P- } \\
\text { probab } \\
\text { ility }\end{array}$ & $\begin{array}{c}\text { hypoth } \\
\text { esis }\end{array}$ & $\begin{array}{c}\text { F- } \\
\text { statis } \\
\text { tics }\end{array}$ & $\begin{array}{c}\text { P- } \\
\text { probab } \\
\text { ility }\end{array}$ & $\begin{array}{c}\text { hypoth } \\
\text { esis }\end{array}$ \\
\hline 0.44 & 0.65 & $H_{0}$ & 0.11 & 0.95 & $H_{0}$ \\
\hline 0.64 & 0.54 & $H_{0}$ & 1.81 & 0.20 & $H_{0}$ \\
\hline
\end{tabular}

Note: Calculated by the author via the eViews software package

\subsection{Causality relationship between import growth and GDP growth}

Calculations show that there is a moderate correlation between $\Delta G D P_{t}$ and $\Delta \dot{\mathrm{I}} M P_{t}$. However, the existence of such a relationship does not yet confirm the existence of a causal relationship between these indicators. However, the Granger test proves that there is no causal relationship between these two indicators, and the hypothesis $H_{0}$ is valid in both directions when lag $=1$ and 2. When Lag = 3 , the hypothesis $H_{0}$ does not justify itself in one direction, or rather in the direction of $\Delta G D P_{t} \rightarrow$ $\Delta \dot{\mathrm{I}} M P_{t}$. In this case, we can say that economic growth in Azerbaijan affects the change in imports with a delay of 3 years. In the opposite direction, there is no causal relationship (Table 1).

Table 1

Results of the Granger test on the effects of changes in the volume of imports in Azerbaijan on changes in GDP and vice versa

\begin{tabular}{|c|c|c|c|}
\hline \multirow{2}{*}{} & \multicolumn{3}{|c|}{$\mathrm{Lag}=1$} \\
\cline { 2 - 4 } & $\begin{array}{c}\mathrm{F}- \\
\text { statistics }\end{array}$ & $\begin{array}{c}\mathrm{P}- \\
\text { probability }\end{array}$ & hypothesis \\
\hline
\end{tabular}




\begin{tabular}{|c|c|c|c|}
\hline$\Delta I M P_{t} \rightarrow \Delta G D P_{t}$ & 0.92 & 0.35 & $H_{0}$ \\
\hline$\triangle G D P_{t} \rightarrow \Delta I M P_{t}$ & 1.76 & 0.20 & $H_{0}$ \\
\hline
\end{tabular}

\begin{tabular}{|c|c|c|c|c|c|}
\hline \multicolumn{3}{|c|}{ Lag=2 } & \multicolumn{3}{c|}{ Lag=3 } \\
\hline $\begin{array}{c}\text { F- } \\
\text { statis } \\
\text { tics }\end{array}$ & $\begin{array}{c}\text { P- } \\
\text { probab } \\
\text { ility }\end{array}$ & $\begin{array}{c}\text { hypoth } \\
\text { esis }\end{array}$ & $\begin{array}{c}\text { F } \\
\text { statis } \\
\text { tics }\end{array}$ & $\begin{array}{c}\text { P- } \\
\text { probab } \\
\text { ility }\end{array}$ & $\begin{array}{c}\text { hypoth } \\
\text { esis }\end{array}$ \\
\hline 0.29 & 0.75 & $H_{0}$ & 0.30 & 0.82 & $H_{0}$ \\
\hline 1.17 & 0.33 & $H_{0}$ & 3.40 & 0.05 & $H_{1}$ \\
\hline
\end{tabular}

Note: Calculated by the author via the eViews software package.

\subsection{Causality relationship between export and GDP}

The linear regression relationship between exports and GDP over the last 23 years is quite strong $\left(R^{2}=\right.$ 0.95). The F-significance level is $7.35^{*} 10^{-15}$. However, to prove that such a strong regression relationship is indeed a cause-and-effect relationship, we must examine the existence of the Granger cause between the time series. Calculations show that for lag $=1,2$ and 3 for $E X P_{t}$ and $G D P_{t}$, the Granger test shows a causal relationship between these two indicators (Table 3). However, such a causal relationship is one-sided, or more precisely, the volume of exports is the cause of GDP.

Table 3

In the case of $\operatorname{Lag}=1 ; 2$ and 3, the results of the Granger test of the effects of exports on GDP in Azerbaijan and vice versa

\begin{tabular}{|l|c|c|c|}
\hline & \multicolumn{3}{|c|}{ Lag=1 } \\
\cline { 2 - 4 } & $\begin{array}{c}\text { F- } \\
\text { statistics }\end{array}$ & $\begin{array}{c}\text { P- } \\
\text { probability }\end{array}$ & hypothesis \\
\hline $\begin{array}{l}E X P_{t} \\
\rightarrow G D P_{t}\end{array}$ & 15.86 & 0.0 & $H_{1}$ \\
\hline $\begin{array}{l}G D P_{t} \\
\rightarrow E X P_{t}\end{array}$ & 3.92 & 0.06 & $H_{0}$ \\
\hline
\end{tabular}

\begin{tabular}{|c|c|c|c|c|c|}
\hline \multicolumn{3}{|c|}{ Lag=2 } & \multicolumn{3}{c|}{ Lag=3 } \\
\hline $\begin{array}{c}\text { F- } \\
\text { statis } \\
\text { tics }\end{array}$ & $\begin{array}{c}\text { P- } \\
\text { probab } \\
\text { ility }\end{array}$ & $\begin{array}{c}\text { hypoth } \\
\text { esis }\end{array}$ & $\begin{array}{c}\text { F- } \\
\text { statis } \\
\text { tics }\end{array}$ & $\begin{array}{c}\text { P- } \\
\text { probab } \\
\text { ility }\end{array}$ & $\begin{array}{c}\text { hypoth } \\
\text { esis }\end{array}$ \\
\hline 4.07 & 0.04 & $H_{1}$ & 4.98 & 0.02 & $H_{1}$ \\
\hline 1.87 & 0.19 & $H_{0}$ & 2.26 & 0.13 & $H_{0}$ \\
\hline
\end{tabular}

Note: Calculated b0y the author via the eViews software package.

\subsection{Causality relationship between export growth and GDP growth}

Calculations show that there is a high degree of correlation between $\triangle G D P_{t}$ and $\triangle E X P_{t}$
$\left(R^{2}=0.778252 ;\right.$ F-significance rate $\left.=5.67 * 10^{-8}\right)$. However, the seriousness of such a relationship between these indicators does not justify its causal relationship. Calculations show that according to the Granger test between changes in exports and GDP on the basis of 1,2 and 3-year lags, there is no causal relationship in both directions, and for Azerbaijan these two indicators are not conditioned (Table 4). It should be noted that at first glance, the steady increase in exports over the past 20 years with the increase in GDP allowed us to draw the wrong conclusion that the main reason for the increase in exports in Azerbaijan is the increase in GDP. Or, conversely, the increase in exports is due to an increase in GDP. However, the Granger test proves that there is no causal relationship between these two indicators and lag $=1 ; 2$; In the case of 3, the hypothesis $H_{0}$ is valid in both directions. Unlike the one-way causality between the volume of exports and the volume of GDP, there is no causality in the relationship between changes in these indicators. In other words, changes in Azerbaijan's exports do not lead to GDP growth. Also, GDP growth does not lead to changes in exports.

Table 4

In the case of $\operatorname{Lag}=1 ; 2$ and 3, the results of the Granger test on the effects of changes in the volume of exports in Azerbaijan on changes in GDP and vice versa

\begin{tabular}{|l|c|c|c|}
\hline & \multicolumn{3}{|c|}{ Lag=1 } \\
\cline { 2 - 4 } & $\begin{array}{c}\text { F- } \\
\text { statistics }\end{array}$ & $\begin{array}{c}\text { P- } \\
\text { probability }\end{array}$ & hypothesis \\
\hline $\begin{array}{l}\Delta E X P_{t} \\
\rightarrow \Delta G D P_{t}\end{array}$ & 1.80 & 0.20 & $H_{0}$ \\
\hline $\begin{array}{l}\Delta G D P_{t} \\
\rightarrow \Delta E X P_{t}\end{array}$ & 1.10 & 0.31 & $H_{0}$ \\
\hline
\end{tabular}

\begin{tabular}{|c|c|c|c|c|c|}
\hline \multicolumn{3}{|c|}{ Lag=2 } & \multicolumn{3}{c|}{ Lag=3 } \\
\hline $\begin{array}{c}\text { F- } \\
\text { statis } \\
\text { tics }\end{array}$ & $\begin{array}{c}\text { P- } \\
\text { probab } \\
\text { ility }\end{array}$ & $\begin{array}{c}\text { hypoth } \\
\text { esis }\end{array}$ & $\begin{array}{c}\text { F- } \\
\text { statist } \\
\text { ics }\end{array}$ & $\begin{array}{c}\text { P- } \\
\text { probab } \\
\text { ility }\end{array}$ & $\begin{array}{c}\text { hypot } \\
\text { hesis }\end{array}$ \\
\hline 0.64 & 0.54 & $H_{0}$ & 1.99 & 0.17 & $H_{0}$ \\
\hline 0.52 & 0.60 & $H_{0}$ & 1.09 & 0.39 & $H_{0}$ \\
\hline
\end{tabular}

Note: Calculated by the author via the eViews software package.

\subsection{Causality relationship between trade balance and GDP}

The linear regression relationship between trade balance and GDP over the last 23 years is quite strong $\left(R^{2}=0.69\right)$. The F-significance level is $7.64 * 10^{-7}$. However, to prove that such a strong 
regression relationship is indeed a cause-and-effect relationship, we must examine the existence of the Granger cause between the time series. Calculations show that for lag $=2$ and 3 for $T B_{t}$ and $G D P_{t}$, the Granger test shows no causal relationship between these two indicators (Table 5). The Granger test shows that in the case of lag $=1$, there is a one-way, ie causal relationship from the trade balance to the volume of GDP. However, if we consider that $T B_{t}$ and $G D P_{t}$ are not stationary time series, then it is doubtful that such a relationship is true.

Table 5

Results of the Granger test of the effects of the trade balance on GDP and vice versa in Azerbaijan

\begin{tabular}{|l|c|c|c|}
\hline & \multicolumn{3}{|c|}{ Lag=1 } \\
\cline { 2 - 4 } & $\begin{array}{c}\text { F- } \\
\text { statistics }\end{array}$ & $\begin{array}{c}\text { P- } \\
\text { probability }\end{array}$ & hypothesis \\
\hline$T B_{t}$ & 7.27 & 0.01 & $H_{1}$ \\
$\rightarrow G D P_{t}$ & & & $H_{0}$ \\
\hline $\begin{array}{l}G D P_{t} \\
\rightarrow T B_{t}\end{array}$ & 1.49 & 0.24 & \\
\hline
\end{tabular}

\begin{tabular}{|c|c|c|c|c|c|}
\hline \multicolumn{3}{|c|}{ Lag=2 } & \multicolumn{3}{c|}{ Lag=3 } \\
\hline $\begin{array}{c}\text { F- } \\
\text { statis } \\
\text { tics }\end{array}$ & $\begin{array}{c}\text { P- } \\
\text { probab } \\
\text { ility }\end{array}$ & $\begin{array}{c}\text { hypoth } \\
\text { esis }\end{array}$ & $\begin{array}{c}\text { F- } \\
\text { statis } \\
\text { tics }\end{array}$ & $\begin{array}{c}\text { P- } \\
\text { probab } \\
\text { ility }\end{array}$ & $\begin{array}{c}\text { hypoth } \\
\text { esis }\end{array}$ \\
\hline 1.65 & 0.22 & $H_{0}$ & 1.61 & 0.23 & $H_{0}$ \\
\hline 0.61 & 0.56 & $H_{0}$ & 0.64 & 0.60 & $H_{0}$ \\
\hline
\end{tabular}

Note: Calculated by the author via the eViews software package

\subsection{Causality relationship between trade balance growth and GDP growth}

Calculations show that there is also a high degree of correlation between GDP and $\triangle T B_{t}$ $\left(R^{2}=0.646407 ;\right.$ F-significance rate $\left.=6.54 * 10^{-6}\right)$. However, the seriousness of such a relationship between these indicators does not justify its causal relationship. Calculations show that according to the Granger test between the trade balance and GDP changes on the basis of 1,2 and 3-year lags, there is no causal relationship in both directions, and for Azerbaijan these two indicators are not conditioned. It should be noted that although one of the main components in the calculation of GDP on the basis of costs is "net foreign trade", in other words, "trade balance", the Granger test proves that there is no causal relationship between these two indicators and lag $=1 ; 2$; In the case of 3 , the hypothesis $H_{0}$ is valid in both directions.

Table 6
Results of the Granger test on the effects of changes in the trade balance in Azerbaijan on changes in GDP and vice versa

\begin{tabular}{|l|c|c|c|}
\hline & \multicolumn{3}{|c|}{ Lag=1 } \\
\cline { 2 - 4 } & $\begin{array}{c}\text { F- } \\
\text { statistics }\end{array}$ & P-probability & hypothesis \\
\hline $\begin{array}{l}\Delta T B_{t} \\
\rightarrow \Delta G D P_{t}\end{array}$ & 2.70 & 0.12 & $H_{0}$ \\
\hline $\begin{array}{c}\Delta G D P_{t} \\
\rightarrow \Delta T B_{t}\end{array}$ & 2.21 & 0.15 & $H_{0}$ \\
\hline
\end{tabular}

\begin{tabular}{|c|c|c|c|c|c|}
\hline \multicolumn{3}{|c|}{ Lag=2 } & \multicolumn{3}{c|}{ Lag=3 } \\
\hline $\begin{array}{c}\text { F- } \\
\text { statis } \\
\text { tics }\end{array}$ & $\begin{array}{c}\text { P- } \\
\text { probab } \\
\text { ility }\end{array}$ & $\begin{array}{c}\text { hypoth } \\
\text { esis }\end{array}$ & $\begin{array}{c}\text { F- } \\
\text { statis } \\
\text { tics }\end{array}$ & $\begin{array}{c}\text { P- } \\
\text { probab } \\
\text { ility }\end{array}$ & $\begin{array}{c}\text { hypoth } \\
\text { esis }\end{array}$ \\
\hline 0.93 & 0.42 & $H_{0}$ & 1.96 & 0.17 & $H_{0}$ \\
\hline 1.85 & 0.19 & $H_{0}$ & 1.50 & 0.27 & $H_{0}$ \\
\hline
\end{tabular}

Note: Calculated by the author via the eViews software package

\subsection{Causality relationship between trade turnover and GDP}

The linear regression relationship between trade turnover and GDP over the last 23 years is quite strong $\left(R^{2}=0.97\right)$. The F-significance level is $9^{*} 10^{-18}$. However, to prove that such a strong regression relationship is indeed a cause-and-effect relationship, we must examine the existence of the Granger cause between the time series. Calculations show that for $T T$ and $G D P_{t} \mathrm{t}$ lag $=1$, the Granger test shows that there is a two-way causal relationship between these two indicators (Table 7). However, in the case of lag $=2$ and 3, the Granger test shows that there is no causal relationship between these two indicators in any direction.

Table 7

Results of the Granger test of the effects of trade turnover on GDP and vice versa in Azerbaijan

\begin{tabular}{|l|c|c|c|}
\hline & \multicolumn{3}{|c|}{ Lag=1 } \\
\cline { 2 - 4 } & $\begin{array}{c}\text { F- } \\
\text { statistics }\end{array}$ & P-probability & hypothesis \\
\hline$T T_{t}$ & 9.93 & 0.01 & $H_{1}$ \\
$\rightarrow G D P_{t}$ & & & $H_{1}$ \\
\hline $\begin{array}{l}G D P_{t} \\
\rightarrow T T_{t}\end{array}$ & 5.07 & 0.04 & \\
\hline
\end{tabular}

\begin{tabular}{|c|c|c|c|c|c|}
\hline \multicolumn{3}{|c|}{ Lag=2 } & \multicolumn{3}{c|}{ Lag=3 } \\
\hline $\begin{array}{c}\text { F- } \\
\text { statis } \\
\text { tics }\end{array}$ & $\begin{array}{c}\text { P- } \\
\text { probab } \\
\text { ility }\end{array}$ & $\begin{array}{c}\text { hypoth } \\
\text { esis }\end{array}$ & $\begin{array}{c}\text { F- } \\
\text { statis } \\
\text { tics }\end{array}$ & $\begin{array}{c}\text { P- } \\
\text { probab } \\
\text { ility }\end{array}$ & $\begin{array}{c}\text { hypoth } \\
\text { esis }\end{array}$ \\
\hline 2.99 & 0.08 & $H_{0}$ & 2.00 & 0.16 & $H_{0}$ \\
\hline 1.46 & 0.26 & $H_{0}$ & 1.64 & 0.23 & $H_{0}$ \\
\hline
\end{tabular}


Note: Calculated by the author via the eViews software package

\subsection{Causality relationship between trade turnover growth and GDP growth}

Calculations show that there is also a high degree of correlation between $\triangle G D P$ and $\Delta T T_{t}\left(R^{2}=0.82 ; \mathrm{F}\right.$ significance rate $\left.=5.27 * 10^{-9}\right)$. However, the seriousness of such a relationship between these indicators does not justify its causal relationship. Calculations show that according to the Granger test, there is no causal relationship between trade turnover and GDP change on the basis of 1,2 and 3year lags, and for Azerbaijan these two indicators are not conditioned and the hypothesis $H_{0}$ is valid in both directions ( Table 8 ).

\section{Table 8}

Results of the Granger test on the effects of changes in trade turnover in Azerbaijan on changes in GDP and vice versa

\begin{tabular}{|l|c|c|c|}
\hline & \multicolumn{3}{|c|}{ Lag=1 } \\
\cline { 2 - 4 } & $\begin{array}{c}\mathrm{F}- \\
\text { statistics }\end{array}$ & $\begin{array}{c}\text { P- } \\
\text { probability }\end{array}$ & hypothesis \\
\hline $\begin{array}{l}\Delta T T_{t} \\
\rightarrow \Delta G D P_{t}\end{array}$ & 0.79 & 0.39 & $H_{0}$ \\
\hline $\begin{array}{l}\Delta G D P_{t} \\
\rightarrow \Delta T T_{t}\end{array}$ & 0.31 & 0.58 & $H_{0}$ \\
\hline
\end{tabular}

\begin{tabular}{|c|c|c|c|c|c|}
\hline \multicolumn{3}{|c|}{ Lag=2 } & \multicolumn{3}{c|}{ Lag=3 } \\
\hline $\begin{array}{c}\text { F- } \\
\text { statis } \\
\text { tics }\end{array}$ & $\begin{array}{c}\text { P- } \\
\text { probab } \\
\text { ility }\end{array}$ & $\begin{array}{c}\text { hypoth } \\
\text { esis }\end{array}$ & $\begin{array}{c}\text { F- } \\
\text { statis } \\
\text { tics }\end{array}$ & $\begin{array}{c}\text { P- } \\
\text { probab } \\
\text { ility }\end{array}$ & $\begin{array}{c}\text { hypoth } \\
\text { esis }\end{array}$ \\
\hline 0.33 & 0.73 & $H_{0}$ & 1.00 & 0.43 & $H_{0}$ \\
\hline 0.12 & 0.89 & $H_{0}$ & 0.33 & 0.80 & $H_{0}$ \\
\hline
\end{tabular}

Note: Calculated by the author via the eViews software package

\subsection{Causality relationship between trade freedom and GDP}

Calculations show that the correlation between $\triangle G D P_{t}$ and freedom of trade $\left(T F_{t}\right)$ in Azerbaijan is very weak $\left(R^{2}=0.001879 ; \mathrm{F}\right.$-significance $=$ 0.848085). However, the timing of both indicators is stationary. Taking this into account, if we perform the Granger test on the basis of 1,2 and 3-year lags between these indicators, we will see that there is no causal relationship in any direction, and for Azerbaijan these two indicators do not condition each other (Table 9).

Table 9
The results of the Granger test on the impact of the level of trade freedom in Azerbaijan on changes in GDP and vice versa

\begin{tabular}{|l|c|c|c|}
\hline & \multicolumn{3}{|c|}{ Lag=1 } \\
\cline { 2 - 4 } & $\begin{array}{c}\text { F- } \\
\text { statistics }\end{array}$ & $\begin{array}{c}\text { P- } \\
\text { probability }\end{array}$ & hypothesis \\
\hline $\begin{array}{l}T F_{t} \\
\rightarrow \Delta G D P_{t}\end{array}$ & 0.04 & 0.84 & $H_{0}$ \\
\hline $\begin{array}{l}\Delta G D P_{t} \\
\rightarrow T F_{t}\end{array}$ & 0.38 & 0.54 & $H_{0}$ \\
\hline
\end{tabular}

\begin{tabular}{|c|c|c|c|c|c|}
\hline \multicolumn{3}{|c|}{ Lag=2 } & \multicolumn{3}{c|}{ Lag=3 } \\
\hline $\begin{array}{c}\text { F- } \\
\text { statis } \\
\text { tics }\end{array}$ & $\begin{array}{c}\text { P- } \\
\text { probab } \\
\text { ility }\end{array}$ & $\begin{array}{c}\text { hypoth } \\
\text { esis }\end{array}$ & $\begin{array}{c}\text { F- } \\
\text { statis } \\
\text { tics }\end{array}$ & $\begin{array}{c}\text { P- } \\
\text { probab } \\
\text { ility }\end{array}$ & $\begin{array}{c}\text { hypoth } \\
\text { esis }\end{array}$ \\
\hline 0.44 & 0.65 & $H_{0}$ & 0.69 & 0.58 & $H_{0}$ \\
\hline 0.91 & 0.42 & $H_{0}$ & 0.98 & 0.43 & $H_{0}$ \\
\hline
\end{tabular}

Note: Calculated by the author via the eViews software package

\subsection{Causality relationship between trade openness and GDP growth}

Calculations show that the correlation between , $\triangle G D P_{t}$ and foreign trade vulnerability $\left(T O_{t}\right)$ is also very weak. $\left(R^{2}=0.135\right.$; F-significance rate $=$ $0.093)$. Given the stationary nature of the time series of both indicators, if we perform the Granger test on the basis of 1,2 and 3-year lags, we see that there is no causal relationship between these two indicators lag $=1$ and 3, and in these cases the hypothesis H_Ois valid in both directions ( Table 10). However, in the case of lag $=2$, there is a one-way causal relationship, ie the change in GDP from the openness of foreign trade $T O_{t} \rightarrow \Delta G D P_{t}$.

Table 10

Results of the Granger test on the impact of the level of trade openness in Azerbaijan on changes in GDP and vice versa

\begin{tabular}{|l|c|c|c|}
\hline & \multicolumn{3}{|c|}{ Lag=1 } \\
\cline { 2 - 4 } & $\begin{array}{c}\text { F- } \\
\text { statistics }\end{array}$ & $\begin{array}{c}\text { P- } \\
\text { probability }\end{array}$ & hypothesis \\
\hline $\mathrm{TO}_{t}$ & 1.39 & 0.25 & $H_{0}$ \\
\hline$\Delta G D P_{t}$ & & 0.48 & $H_{0}$ \\
\hline $\begin{array}{l}\Delta G D P_{t} \\
\rightarrow T O_{t}\end{array}$ & 0.51 & & \\
\hline
\end{tabular}

\begin{tabular}{|c|c|c|c|c|c|}
\hline \multicolumn{3}{|c|}{ Lag=2 } & \multicolumn{3}{c|}{ Lag=3 } \\
\hline $\begin{array}{c}\text { F- } \\
\text { statis } \\
\text { tics }\end{array}$ & $\begin{array}{c}\text { P- } \\
\text { probab } \\
\text { ility }\end{array}$ & $\begin{array}{c}\text { hypoth } \\
\text { esis }\end{array}$ & $\begin{array}{c}\text { F- } \\
\text { statis } \\
\text { tics }\end{array}$ & $\begin{array}{c}\text { P- } \\
\text { probab } \\
\text { ility }\end{array}$ & $\begin{array}{c}\text { hypoth } \\
\text { esis }\end{array}$ \\
\hline 3.59 & 0.05 & $H_{1}$ & 2.25 & 0.14 & $H_{0}$ \\
\hline 0.54 & 0.60 & $H_{0}$ & 0.38 & 0.77 & $H_{0}$ \\
\hline
\end{tabular}


Note: Calculated by the author

\section{Conclusion}

Thus, the Granger test examines the cause and effect of GDP and its dependence on indicators that characterize foreign trade activity, including imports, exports, trade balance, trade turnover, trade freedom and trade openness, among these indicators in Azerbaijan. cause-and-effect relationships are very weak. The main reason for this is most likely that the bulk of the country's GDP is related to oil and gas production.

\section{References:}

[1] Akanni, O.P. Oil Wealth and Economic Growth in Oil Exporting Countries, AERC Research Paper, 2007, p.170.

[2] Balaguer, M. Exports and Economic Growth in Bangladesh. Journal of Development Studies, 35(1),2002,pp. , 89-114.

[3] Davidson R. and MacKinnon J.G. Estimation and İnference in Econometrics, New York: Oxford University Press, 1993, p. 708.

[4]Erfani, H.S. Exports, Imports and Economic Growth in Semi-industrialized countries. Journal of Development Economics, 35, 1999, pp. 93116.

[5] Gemechu, G. Exports and Economic Growth in Ethiopia - Addis Ababa. Retrieved from University.etd.auu.edu.et/displace/bitsream/, 2002, p. 123.

[6]ITA. International Trade Administration. Trade Regulations, Customs and Standards. https://2016.export.gov/singapore/doingbusinessi nsingapore/traderegulationscustomsandstandards /index.asp\#P11_314, 2020

[7]Lin, F.C. Export - led Growth and the four little Dragons. Journal of International Trade and Economic Development, 4(2), 1995, pp. 203-15.

[8] Vohra. Exports and Economic Growth in Developing Countries. Evidence from Time Series and Cross-Section Data. Journal of Economic Development and Cultural Change, 36, 2001, pp. 51-72. 